\title{
Article \\ Reflective Practice: Co-Creating Reflective Activities for Pharmacy Students
}

\author{
Kalbie Hokanson ${ }^{1}$, Rene R. Breault ${ }^{1} \mathbb{D}$, Cherie Lucas $^{2}$, Theresa L. Charrois ${ }^{1}$ and Theresa J. Schindel $^{1, *(D)}$ \\ 1 Faculty of Pharmacy and Pharmaceutical Sciences, College of Health Sciences, University of Alberta, \\ Edmonton, AB T6G 2H7, Canada; kalbie@ualberta.ca (K.H.); rbreault@ualberta.ca (R.R.B.); \\ teri.charrois@ualberta.ca (T.L.C.) \\ 2 Graduate School of Health, University of Technology Sydney, Sydney, NSW 2007, Australia; \\ cherie.lucas@uts.edu.au \\ * Correspondence: terri.schindel@ualberta.ca
}

check for updates

Citation: Hokanson, K.; Breault, R.R.; Lucas, C.; Charrois, T.L.; Schindel, T.J. Reflective Practice: Co-Creating Reflective Activities for Pharmacy Students. Pharmacy 2022, 10, 28. https://doi.org/10.3390/ pharmacy10010028

Academic Editor: Jon Schommer

Received: 7 January 2022

Accepted: 8 February 2022

Published: 10 February 2022

Publisher's Note: MDPI stays neutral with regard to jurisdictional claims in published maps and institutional affiliations.

Copyright: (C) 2022 by the authors. Licensee MDPI, Basel, Switzerland. This article is an open access article distributed under the terms and conditions of the Creative Commons Attribution (CC BY) license (https:// creativecommons.org/licenses/by/ $4.0 /)$.

\begin{abstract}
Reflective practice is important in pharmacy education to support skill development for decision-making, critical thinking, problem-solving, and in continuing professional development and beyond. Despite the importance of reflective practice in higher education and professional practice, reflection assignments are not universally embraced by students. This project was initiated due to recent interest in the co-creation of pharmacy curriculum by students and faculty. The purpose of this project was to develop reflection assignments for pharmacy students. The principles of the analysis, design, development, implementation, evaluation (ADDIE) instructional design framework guided the development of reflection assignment templates for three focus areas: personal development, professional development, and professional identity formation. Templates included background and definitions for these specific focus areas as well as objectives, instructions, guiding questions, assessment methods, and submission requirements. A previously tested assessment rubric was adopted for reflection assignments. Development involved target audience and expert reviews and a trial implementation was held in a year 3 patient care skills course. The co-creation process enriched the experiences of students and faculty involved in it. Future co-creation projects including groups of students, formal evaluation of outcomes, and impact on the program will further support integration of reflective practice in the pharmacy curriculum.
\end{abstract}

Keywords: reflective practice; reflection; reflective writing; pharmacy education; co-creation; assessment

\section{Introduction}

Reflective practice is an integral part of the pharmacy curriculum. It supports development of skills in decision-making, critical thinking, problem-solving, and is important for continuing professional development and ongoing professional practice [1]. Reflection is defined differently depending on the philosophical tradition or conceptual framework in which this multi-faceted construct is being discussed [2,3]. Scholars have framed reflection as a mindful activity providing insights about thinking [4], a process in which experience may be explored [5] or perspectives changed [6]. According to Dewey, reflection is concerned with how thinking occurs as an active and iterative process [4]. Kolb highlights reflection as integral to learning from experience [7]. Boud et al. introduce the role of emotion in the process of reflection, which involves exploring personal experience with the purpose of new understanding and insights [5]. Mezirow advocates for critical reflection with the aim of transforming personal perspectives and effecting social change [6]. Brookfield also takes a critical approach, emphasizing conscious and unconscious aspects of the reflective process through exploring assumptions through various lenses (theory, peer, students, self) [8]. Schon introduces the concept of the reflective practitioner, bringing together theory and everyday practice [9]. Often initiated by a puzzling or surprising event, 
reflection on current situations (reflection-in-action) and previous experiences (reflectionon-action) brings new perspectives about a situation that may stimulate a new approach in the future [9]. Both personal knowledge and perspectives of others may be involved. Drawing on prominent writings about reflection, Nguyen et al. develop a unified definition as "the process of engaging the self in attentive, critical, exploratory and iterative interactions with one's thoughts and actions, and their underlying conceptual frame, with a view to changing them and with a view on the change itself" [2] (p. 1182).

Reflection has long been incorporated into educational activities and assessments in the context of higher education; it can be a valuable part of a student-centred approach and a means to reinforce the importance of experience as a basis for developing knowledge and skills [10,11]. Reflection on experience facilitates construction of new knowledge and understanding, thereby supporting development for future professional roles [9,12]. In educational settings for the health professions, reflection has been shown to support development of empathy [13], confidence [14], problem-solving skills and skills for coping with uncertainty [11], and relationships with instructors [15]. In pharmacy programs specifically, reflective activities have supported development of a range of skills and abilities including critical appraisal [16], reflective thinking [1], clinical decision-making [17], connecting classroom and experiential learning [18], identifying own learning needs and self-directed learning [16,19] and maximizing learning from clinical placement experiences [20].

Various educational strategies support the development of reflective practice skills; written, verbal, and artistic approaches have been taken $[15,21,22]$. Reflective writing may take several forms such as essays, blogs, journals, diaries, professional development plans, and learning portfolios. Examples of verbal approaches include storytelling, podcasts, and peer discussions. Poetry, painting, drawing, sculpture, and photography have also been used. The educational strategy used depends on the intended outcome and the needs of the student [22]. Some students in healthcare and pharmacy programs perceive value in reflective activities [1,16,18], while others perceive them as challenging [1,23] or burdensome [14], questioning the value of completing as well as objectivity and transparency of grading reflections $[13,24,25]$. Despite the importance of and emphasis on reflective practice in higher education, students may not understand the purpose of reflection assignments nor their relevance to learning and future practice $[12,16]$. Research has shown that acceptance by students and their ability to engage in and benefit from reflective activities improve when educators provide structured learning experiences with information regarding expectations, clear assessment criteria, adequate guidance, and helpful feedback $[10,13,16,20,22,23]$. Incorporating students' perspectives on reflection and involving them in the development of educational activities may also influence how they engage with reflective practice $[20,25,26]$. Considering the student perspective is essential to building reflective activities that are not seen as ineffectual by students $[12,25,26]$. Given the importance of reflective practice, exploring educational strategies to address these challenges with student engagement warrant exploration.

There has been growing interest in students and faculty working together to create curricula in recent years [27]. In this project, working with a third-year pharmacy student, we explored and developed reflective practice activities for pharmacy education at an entry-to-practice level. This article aims to describe our co-creation process for the development of reflection assignments for pharmacy students using the ADDIE instructional design framework.

\section{Materials and Methods}

\subsection{Educational Setting}

The Faculty of Pharmacy and Pharmaceutical Sciences, College of Health Sciences at the University of Alberta offers an entry-to-practice Doctor of Pharmacy (PharmD) program [28]. PharmD students complete a minimum of two years of pre-requisite courses prior to starting the four-year program [29]. Each year has three terms: fall, winter, and spring/summer. The first three years of the program include foundational courses in five 
curricular streams taught in the fall and winter terms: Pharmaceutical Sciences, Behavioural, Administrative, Social, and Evidence-based (BASE) pharmacy, Pharmacotherapy, Patient Care Skills, and Interprofessional Education. The sixth stream, the Experiential Education stream, is delivered in the spring/summer terms, beginning with years 1 and 2 ( 8 weeks). Inclass instruction occurs in knowledge-based classes, such as pharmacology and therapeutics. There are also personal development courses incorporating ethics, communication, and self-reflection. Year 4 of the program involves Experiential Education placements (32 weeks) in a variety of practice settings (e.g., community pharmacies, hospitals, ambulatory care, pharmacy organizations) and integrated seminars where students convene in groups to discuss and explore their experiences in pharmacy practice. Students must also complete one elective course, choosing from available courses in various curricular streams, including a Research and Directed Studies course option, before or during year 3 of the program. Approximately 130 students are admitted each year.

Educational outcomes for the PharmD program include reflective practice and metacognitive skills, that is, the ability to reflect on knowledge, skills, and beliefs that could influence self-development and professional performance [30]. Reflection on teaching approaches (see Schindel et al. [31]) and reflection on learning (see Nagy et al. [32]) are both important. Students are introduced to the theoretical foundations of reflection in year 1 of the program and are required to complete a variety of reflective activities, such as written reflections and group discussions, in conjunction with in-class courses, practice skills laboratories, and experiential education placements. While reflective activities are included in various aspects of the programs and within curricular streams, these activities are not mapped; thus, their implementation across curricular streams or the entire four years of the program may be inconsistent and sporadic.

\subsection{Conceptual Framework}

The development, implementation, and evaluation of reflective activities for pharmacy students in this study was based on the concept of co-creation [27]. Co-creation encompasses active learning, student engagement, shared decision-making, and negotiation [33]. According to Bovill et al., co-creation occurs "when staff and students work collaboratively with one another to create components of curricula and/or pedagogical approaches" [27] (p. 196). Throughout this process, students' perspectives and contributions are recognized and valued, and the traditional hierarchy between teacher and students is diminished [33]. In partnership with faculty, students may adopt different roles in the co-creation process such as consultant, co-researcher, co-designer, or student representative [27]. Benefits of co-creation may include a socially relevant curriculum [34], an improved learning environment [35], deeper engagement in learning and teaching activities [27], enriched meta-cognitive understanding of learning and teaching processes [35], enhanced understanding of students themselves [36], development of attributes that maximize employability post-graduation [27], and transformation through disrupting previous ways of learning or teaching, reflecting on experiences, acting in new ways, and integrating new perspectives [33]. Challenges for the learner relate to unfamiliarity with the process, role, and responsibility involved in co-creation; a power imbalance may also develop due to the necessity for assessment in university programs and lack of student involvement with implementation [35]. For teachers, challenges may arise due to changes in the control of the learning environment, perceived threats associated with change, and time required for the co-creation process $[35,36]$.

\subsection{Instructional Design}

Principles of the analysis, design, development, implementation, evaluation (ADDIE) instructional design framework guided the development of reflection assignment templates for this co-creation project [37,38]. The first author $(\mathrm{KH})$, when entering year 3 of the PharmD program, engaged with the analysis, design, and development phases of the project as a co-designer [27]. This co-creating role for one student $(\mathrm{KH})$ was integrated 
in conjunction with a directed studies elective course completed April to June 2020. The reflective practice topic was chosen by the student from a list of possible directed study projects. It was supervised by one faculty member (TJS) and supported by the other authors (RRB, CL, TLC). The implementation and evaluation phases were completed after the conclusion of the directed studies course (RRB). The University of Alberta Research Ethics Board 2 approved the evaluation (Pro001020270).

\section{ADDIE Framework}

\subsection{Analysis}

The main consideration in the ADDIE analysis phase was to identify the needs of the target audience. A multi-faceted approach to analysis was undertaken. It began with the student $(\mathrm{KH})$ becoming familiar with reflective practice and educational outcomes for the program [30], reviewing selected literature on reflective practice and related instructional approaches in pharmacy and health sciences programs $[13,16,19,20,25,39-42]$, reviewing reflective practice assignments in PharmD course syllabi, discussing with the supervisor (TJS), and ruminating on personal experiences with reflective practice. As part of this phase, the first author $(\mathrm{KH})$ documented an initial reflection:

My interest in this project stems from my own experiences with reflection. My mother is an advocate of reflection and was a role model for me, so I had some experience with reflecting on experiences. One experience stands out for me related to an OSCE-style exam in the first year of the program. I recall experiencing intense nervousness during the exam. When I left the exam, I was unhappy with one of my answers. Usually when this happens, I am satisfied to review what I recall about questions and answers and continue on. However, in this situation, my discomfort troubled me for days following the exam. I asked myself questions such as: "Will I ever be able to learn all I need to know?" or "Is this experience going to drive my self-confidence as a student?" After discussions with my mother and time to process the event, I came to the realization that making a mistake in a safe environment is okay as a learner and was able to move beyond the experience. This outcome reinforced the value of reflection to me. As a result, my dedication to reflective practice for personal and professional growth has remained strong. My positive regard for reflective practice is not status quo among all of my classmates. I understand that a large portion of classmates dislike the process of reflection and the associated assignments. Fellow students comment that reflections are a "waste of time", "not valuable", "a time-filler" or "taught wrong," which were similar sentiments to what I was reading in the literature. I also learned that these perspectives were shared by students in other programs. This project provides an opportunity for me to understand more about students' perspectives, advocate for students, and contribute to curriculum development with my professors to support reflection and reflective practice for pharmacy students.

Based on the ADDIE analysis phase, the student and supervisor identified strategies needed to support students' development of reflective practice skills: reflection assignments must have a focus, students must have options for formats other than formal written reflections, students must have opportunities for sharing and engaging with peers, assignment expectations must be clear, and formative assessment and feedback must be provided.

\subsection{Design}

In the next phase, core elements of reflective assignments for year 1 of the framework were designed. The information obtained during the analysis phase was considered during the design phase. The activities consisted of creating objectives, specifying learning activities to meet the objectives, and determining how the objectives would be assessed. The first step was to develop overall objectives to address student needs and educational outcomes of the program. It was determined that pharmacy students would be able to:

- Define reflective practice;

- Describe the purpose of reflection; 
- $\quad$ Engage in different types of reflective activities;

- Explore reflective activities individually and with peers;

- Respond to formative and summative assessments;

- Identify changes for future learning or practice; and

- Apply reflective skills in practice.

Learning activities were specified for three areas of focus based on the work of Ash and Clayton [43]: personal development, professional development, and professional identity formation. These focus areas and associated activities were chosen to correspond to various purposes for reflection and different formats (e.g., written, verbal). A reflective rubric with seven elements of reflection, ranging from non-critical to critical, was selected to provide an evidence-based standard assessment strategy for instructors and students [42,44,45].

\subsection{Development}

The development phase involved production and evaluation of assignment templates for personal development (reflection on critical incidents) [8,46], professional development (reflection on learning) [47], and professional identity formation (reflection on practice experiences) [48]. Each template provided background information to explain the focus, objectives, guiding questions, format, and assessment of the reflection. These generic and modifiable templates were intended to be flexible, allowing for possible customizing of the assignment by instructors. These templates were also intended to be made available to students to support their own engagement in the PharmD program and beyond.

\subsubsection{Target Audience Review}

All reflective activities were evaluated in the development phase via target audience review. The objectives of the target audience review were to explore students' initial reactions to the assignment templates and document their perceptions regarding the clarity of instructions, purpose of the assignment, understanding of different types of assignments, and willingness to complete the assignment. Cognitive interviews [49] were conducted $(\mathrm{KH})$ with a purposive sample of students who had completed years 1-3 of the PharmD program [50]. Prospective participants were identified based on the following criteria: availability, interest in reflection, and willingness to provide feedback. Initially, 14 students were contacted via social media to participate, with eight offering their time. The assignment templates were sent to these students $1 \mathrm{~h}$ before their interviews, which were conducted remotely using Zoom due to the COVID-19 pandemic. At the start of each interview, descriptions of the project and purpose of the interview were provided. Procedures to obtain informed consent were followed, and students were informed that their participation was voluntary, they could end the interview at any time, their comments would be anonymous and confidential, and their comments would be used to make improvements to the templates. Each student reviewed two of the assignment templates, which were randomly selected by the interviewer $(\mathrm{KH})$. The cognitive interview involved asking students to share their thoughts, reactions to, and feelings about the assignments. At the end of each interview, the students were invited to ask the interviewer any further questions they had about the assignment templates. Research Ethics Board approval was not required for this aspect of the evaluation since the intent was to inform about development of instructional materials (S. Varnhagen, personal communication, 12 May 2020).

In total, eight interviews that were 30-45 min in duration were held over 4 days in May 2020. Interviews were not recorded. Notes were typed directly onto the assignment document by $\mathrm{KH}$ as the students talked about the assignment templates. Representative evaluation data is provided in Table 1.

Students' initial reactions toward the reflection assignment templates were positive. They expressed appreciation for inclusion of specific objectives and guiding questions they felt would help students direct their learning and recognize different areas of focus for reflection. This appreciation for specificity also extended to the rubric as a guide for expectations. One student commented, "Even if a student wanted to try to fake their way 
through this assignment, they would still be learning something because the points on the rubric are so specific to hit."

Table 1. Representative data from the target audience review.

\begin{tabular}{|c|c|c|}
\hline Focus & What Works Well? & What Could Be Improved? \\
\hline $\begin{array}{l}\text { Reflection for } \\
\text { personal } \\
\text { development }\end{array}$ & $\begin{array}{l}500 \text { words is an appropriate amount for } \\
\text { a reflection. It allows for just } \\
\text { enough filler to provide } \\
\text { background information. } \\
\text { (Year } 2 \text { Student) } \\
\text { I really enjoy the prompting questions. } \\
\text { I could think of an example to reflect on } \\
\text { as soon as I read these questions! } \\
\text { (Year } 1 \text { Student) }\end{array}$ & $\begin{array}{l}\text { Change the wording from "critical } \\
\text { incident" to "significant } \\
\text { incident."(Year 1 Student) } \\
\text { I don't understand the meaning of } \\
\text { "appropriation" of knowledge [in } \\
\text { the rubric]. Is that not the } \\
\text { same as "integrating"? } \\
\text { (Year 1 Student) }\end{array}$ \\
\hline $\begin{array}{l}\text { Reflection for } \\
\text { professional } \\
\text { development }\end{array}$ & $\begin{array}{l}\text { I like having no numerical value/grade } \\
\text { tied to the rubric. I do not believe } \\
\text { students should be assigned a grade on } \\
\text { reflections. How can a grader value one } \\
\text { person's thoughts more } \\
\text { superior to another? } \\
\text { (Year } 3 \text { Student) } \\
\text { I like the variations that allow for peer } \\
\text { feedback. I know I would personally } \\
\text { put more effort into my work if I knew } \\
\text { my colleagues would be looking at it. } \\
\text { (Year 2 Student) }\end{array}$ & $\begin{array}{l}\text { I think asking us [as first-year } \\
\text { students] to complete this } \\
\text { assignment in first semester might } \\
\text { be difficult as we are just beginning } \\
\text { to grasp concepts. } \\
\text { (Year } 1 \text { Student) } \\
\text { I think the student could also reflect } \\
\text { on what the pharmacist is like. Are } \\
\text { they friendly or jaded? Overworked } \\
\text { or bubbling with energy? } \\
\text { (Year 2 Student) }\end{array}$ \\
\hline $\begin{array}{l}\text { Reflection for } \\
\text { professional } \\
\text { identity } \\
\text { formation }\end{array}$ & $\begin{array}{l}\text { Public speaking is a great way to } \\
\text { integrate other skills we need to have as } \\
\text { a professional and allows for a good tie } \\
\text { in with PHARM } 454 \text { [experiential } \\
\text { education-hospital placement]. } \\
\text { (Year } 2 \text { Student) } \\
\text { I like how this rubric is applicable } \\
\text { across all three assignments so we can } \\
\text { integrate the aspects we should be } \\
\text { touching on when reflecting. However, } \\
\text { the rubric is quite wordy, it } \\
\text { could be simplified. } \\
\text { (Year } 3 \text { Student) }\end{array}$ & $\begin{array}{l}\text { Students should be provided } \\
\text { examples of reflection from their } \\
\text { professors and how it has driven } \\
\text { their practice to provide us } \\
\text { [students] with a good reason to use } \\
\text { reflection in the future. } \\
\text { (Year } 2 \text { Student) } \\
\text { I wish the assignments were not so } \\
\text { fragmented [in the curriculum]. I } \\
\text { wish we could have done a } \\
\text { reflective portfolio that could have } \\
\text { been tracked across our four years } \\
\text { of pharmacy so we could see how } \\
\text { we have grown. } \\
\text { (Year } 3 \text { Student) }\end{array}$ \\
\hline
\end{tabular}

Some students had difficulty differentiating between the assignments involving reflection on personal development versus reflection on professional development. This concern was expressed by first-year students who stated that they had not been introduced to the concept of continuing professional development [47]. Students in years 2 and 3 were able to identify and explain the difference.

All students favoured the use of formative assessment over summative assessment. One student questioned whether it was appropriate to assign grades based on a student's personal thoughts and experiences. Students expressed appreciation for the assessment rubric chosen for the assignments [44,45]. In terms of improvements, some students suggested revisions, as they found the assessment rubric too dense.

Students indicated that sharing their reflections with peers enhanced their learning. However, in terms of providing peer assessment for fellow students, there was a mixed response. Students supported the use of peer feedback in situations when there was no grade or risk associated with it. 


\subsubsection{Expert Review}

All reflective activities were also evaluated in the development phase via expert review. Pharmacy educators/researchers with expertise in reflection and innovative instructional approaches to teach patient care skills (CL, TLC) performed expert reviews of the reflection assignment templates. They suggested elaborating on the areas of focus by including references and definitions of critical incident, continuing professional development, and professional identity. They also suggested that students be provided with opportunities to reflect on both positive and negative experiences.

\subsubsection{Reflection Assignment Templates}

Following the target audience and expert reviews, the reflection assignment templates (Appendix A), and assessment rubric (Appendix B) were modified. A possible reflective practice framework incorporating these elements was outlined to guide implementation across the curricular streams in year 1 (Table 2).

Table 2. Possible framework for reflective activities in year 1.

\begin{tabular}{|c|c|c|c|}
\hline & Fall Term & Winter Term & Spring/Summer Term \\
\hline Focus & $\begin{array}{c}\text { Personal } \\
\text { development }\end{array}$ & $\begin{array}{l}\text { Professional } \\
\text { development }\end{array}$ & $\begin{array}{l}\text { Professional identity } \\
\text { formation }\end{array}$ \\
\hline $\begin{array}{l}\text { Concepts taught } \\
\text { in curricular } \\
\text { streams }\end{array}$ & $\begin{array}{l}\text { Reflective practice, } \\
\text { reflection, critical } \\
\text { incident }\end{array}$ & $\begin{array}{l}\text { Learning, continuing } \\
\text { professional } \\
\text { development }\end{array}$ & $\begin{array}{l}\text { Role of pharmacists, } \\
\text { professional identity }\end{array}$ \\
\hline Social & $\begin{array}{l}\text { Student "near peer" } \\
\text { shares experiences } \\
\text { developing } \\
\text { reflective practice }\end{array}$ & Discussion with peers & Sharing with peers \\
\hline Format & $\begin{array}{l}\text { Reflective writing } \\
\text { (Critical incident) }\end{array}$ & $\begin{array}{c}\text { Continuing } \\
\text { professional } \\
\text { development plan } \\
\text { (Learning needs) }\end{array}$ & $\begin{array}{c}\text { Blog entry } \\
\text { (Practice experience) }\end{array}$ \\
\hline Assessment & Formative & Formative, Summative & Formative \\
\hline
\end{tabular}

This framework introduces students to reflection in the three previously mentioned different areas of focus: personal development, professional development, and professional identity formation. In year 1 of the PharmD program at $\mathrm{U}$ of $\mathrm{A}$, foundational concepts are taught in four of the six curricular streams (BASE, Patient Care Skills, Interprofessional Education, and Experiential Education). Including social aspects of reflective practice exposes students to others' stories and thoughts, increasing opportunities for learning $[19,20,41,51]$. The first assignment in the fall term requires reflection on a critical incident [46]. This first reflection is a formative assessment involving a standard rubric and feedback on the reflective process. In the winter term, the focus becomes professional development [47]; both formative and summative assessment could be incorporated using the standard rubric. Reflective activities co-occurring with experiential education placements in the spring/summer term focus on professional identity formation [48]. In all three terms, the assignment format varies; students complete formal written reflections, continuing professional development plans, and informal writing in the form of a blog entry.

In subsequent years, reflection assignments increase in number. Activities vary, and reflection is used for different purposes (e.g., interprofessional collaboration, social justice projects), assigned in different formats (e.g., portfolios, podcasts, exhibits, stories), and assessed using different strategies (e.g., self, peer) to support further development of reflective practice abilities $[9,22,52]$. 


\subsection{Implementation}

Reflection assignment templates were implemented on a trial basis in a year 3 patient care skills course delivered remotely in the Fall 2020 term in conjunction with an evolving effort to develop care planning skills [53] and explore aspects of reflective practice [9]. The course, PHARM 420, is delivered weekly beginning with a one-hour seminar followed by three hours of skills development via simulation and small-group learning. Students were introduced to the reflection assignment during the pre-lab seminar. The assignment required each student to submit a written reflection following the session on a critical incident related to a disagreement with a physician (Appendix C). All 124 students enrolled in the course submitted their reflection assignments. The assignments were graded by the lead instructor (RRB). The assessment rubric was integrated into the content management system, eClass, to facilitate formative feedback on this assignment. Students received a completion grade of $1 \%$.

\subsection{Evaluation}

The instructor's evaluation of the reflection assignment facilitated identification of areas to improve its implementation in this course. While the grading process was essential to provide feedback to the students and assess students' reflective practice ability, grading required several hours of instructor time. The assignments were well done overall; however, a wide variation in students' reflective writing abilities was evident. Based on this experience, adjustments for the Fall 2021 course included changing the format to a small-group activity to simulate reflection-in-practice [9], combining group reflection discussion and writing in the assignment. An additional guiding question prompted students to explore the value of the group reflection and address any disagreement (Appendix C). Following grading of the group submissions, the instructor discussed the activity with all students at the seminar the following week and provided additional feedback verbally in a large group setting. The flexible reflection assignment template allowed the instructor to customize reflective practice activities for this course.

As a result of the implementation of these reflections in the PHARM 420 course, the templates are currently being evaluated and further modified. Future enhancements under consideration include peer assessment and feedback and the use of an online tool to support self-assessment [54].

\section{Discussion}

Researchers and educators have identified numerous challenges in teaching reflective practice skills, highlighting the need for a structured framework for reflection in health education $[19,22]$. Lack of understanding of or engagement in reflection on the part of students has long challenged educators [12,13,16,25]. Applying the concept of co-creation [27], a student-faculty partnership was formed at the University of Alberta's Faculty of Pharmacy and Pharmaceutical Sciences, College of Health Sciences to develop reflection assignment templates. These templates offer guidance and flexibility for instructors to customize reflection assignments for pharmacy students across the curriculum. A previously tested, reliable assessment rubric is applicable to a broad range of settings [44,45]. Initial implementation showed promise, but further development is planned and broader implementation in the PharmD program is anticipated.

Initial evaluation of the templates in the PHARM 420 course encouraged continued use of the rubric to establish specific expectations for reflection and provide feedback to students. Although students questioned the value of graded reflection assignments, there may be situations when summative assessment is appropriate. The tested rubric provides guidance for summative assessment as it utilizes an objective process so that a grade is not related to the student's thoughts, feelings or reactions but related to the fact they had initial thoughts, feelings, and reactions which they would reflect on to change future behaviour $[44,45]$. 
Students can learn much about reflective practice through their interactions with various assessment strategies [42]. Peer assessment may offer an impactful approach to enhance student engagement with reflection assignments, as sharing reflections with peers enhances learning $[13,19,25,41,55,56]$. Implementing self-assessment and peer feedback utilizing the rubric may be feasible for students in years 2 and beyond who have sufficient experience developing their own reflective practice abilities. Further research on the use of peer- and self-assessment in pharmacy education is warranted.

The co-creation process was critical to the outcome of this project. Student voice in curricular development and design of educational materials is imperative for continued improvement of instruction in reflective practice. Students bring a unique viewpoint to the problem, improving our understanding of what students need and why they accept or reject learning activities. Partnering with students who are passionate and willing to improve their understanding of reflective practice can result in development of engaging instructional techniques and materials [57]. Fostering relationships between students and professors as co-creators of the curriculum can give them both insight into each other's challenges, allowing for growth, understanding, and empathy $[33,36,57,58]$.

Co-creation projects can also promote further development of meta-cognitive abilities and transformative learning [33], as is evident in this reflection (KH):

As a student who has never attempted creating educational materials, this was a very eyeopening experience. Now I can understand the work and time that has to go into creating these assignments; it is not as simple as writing up a task with a rubric. My primary goal going into this project was to increase the positive perception and understanding of reflective practices for the next generation of professionals. Was I able to achieve this? Yes, and no. I feel I was able to increase the positive notion behind reflection among the students who were part of the project. However, they make up an incredibly small portion of our student body. I also feel I was able to increase my own understanding of reflection and reflective practices through reading and analyzing journal articles.

The major change of heart (my own critical incident) I experienced during this project occurred when students reviewed the reflection assignment template for personal development with the option to share a reflection with a peer. My assumption was that students would embrace the opportunity to "save face" and remain anonymous when sharing their reflections and experiences with other students. Students loved the idea of discussion boards to anonymously post reflections and learning experiences with one another. However, when it came to the peer feedback, students stated they would prefer the reviewers be identified. Students related this to what they have learned in the PharmD program. They recalled that during lectures and learning to give feedback, they were taught the CORBS model [59]. The "O" stands for owned. Students stated commitment to best practices of feedback and to be honest with who is providing the review. My perspective changed because of this experience. I originally thought students would prefer anonymous feedback. My assumptions were reinforced by what I was reading in the literature. I see now this is not the case. I have a new appreciation for seeking input from students representing the target audience for the learning activity.

For the student involved in the co-creation process, there were several experiences that could not be attained in a classroom. Originally, this project was intended to promote a shared understanding of the necessity of reflective practice for professional growth. However, the different aspects of the co-creation process increased the student's passion and encouraged the use of reflection for the purpose of growth. Additionally, the project incorporated aspects of instructional design, research, and academic writing. With no previous experience in these areas, the student found that it was an incredible opportunity to be immersed in this kind of work, even with all the emotional ups and downs involved in writing, editing, reviewing, and submitting an article for publication. These realities are acknowledged within the academic world, but it is difficult to truly understand until you are placed in the same position [60]. Finally, the project fostered several positive 
relationships among faculty members and students. In this directed studies course project, where a power hierarchy is inevitable [36], the student $(\mathrm{KH})$ received enthusiastic support. While co-creation typically aims to produce positive effects for students directly involved in co-creation, engagement by more students has potential for greater impact on students' experiences [35].

Given the breadth of research and literature on reflection and reflective practice in a variety of disciplines, one limitation of this project is that some teaching and learning techniques may have been overlooked. This limitation was mitigated somewhat by the expertise of the individuals involved in the project. The co-creation process primarily involved one student and eight other students contributing to aspects of the development phase of the project. With respect to student voice, the purposive sampling method in the development phase did not represent all student perspectives; therefore, bias associated with the purposive sampling method may have influenced results. Future co-creation projects may benefit from involvement of larger groups of students [36]. Another limitation relates to the lack of representation from year 4 students and pharmacy graduates who may have valuable insights into what reflective practice means to them now that they have completed their entry-to-practice degrees. Despite these limitations, the cognitive interview method successfully gleaned specific and detailed information about what matters to students. Their insights enhanced the reflection assignment templates and assessment rubric. Further development, implementation, and evaluation in future will provide additional data based on views and experiences of students and instructors using the assignment templates, as well as the impact of co-creation on the learning environment, motivation of learners, and quality of the education design [35].

\section{Conclusions}

This project applied a co-creation process to develop reflective practice activities for pharmacy students using the ADDIE instructional design framework. Assignment templates were developed in three specific areas of focus for reflection: personal development, professional development, and professional identity formation. Initial implementation in a patient care skills course reinforced the flexibility of the templates that can be customized in future to meet course goals and student needs. The co-creation process enriched the experiences of students and faculty involved in the project. Future projects may include larger groups of students and formal evaluation of student and instructor experience as well as the impact of co-creation on the program.

Author Contributions: Conceptualization, K.H. and T.J.S.; methodology, T.J.S.; validation, K.H., R.R.B., C.L., T.L.C. and T.J.S.; formal analysis, K.H., R.R.B. and T.J.S.; investigation, K.H., R.R.B. and T.J.S.; resources, T.J.S.; data curation, R.R.B. and T.J.S.; writing—original draft preparation, K.H. and T.J.S.; writing-review and editing, R.R.B., C.L. and T.L.C.; visualization, T.J.S.; supervision, T.J.S.; project administration, T.J.S. All authors have read and agreed to the published version of the manuscript.

Funding: This research received no external funding.

Institutional Review Board Statement: This project was approved by Research Ethics Board 2 of UNIVERSITY OF ALBERTA (Pro00102027, 22 November 2021).

Informed Consent Statement: Informed consent was obtained from all subjects involved in the project.

Data Availability Statement: Not applicable.

Acknowledgments: The authors are grateful to the Doctor of Pharmacy students who provided evaluative comments and feedback for this project.

Conflicts of Interest: The authors declare no conflict of interest. 


\section{Appendix A. Reflection Assignment Templates}

\section{Appendix A.1. Personal Development}

Background: A critical incident is a learning situation which learners have experienced as effective, exceptional, or personally meaningful which may lead to educationally significant learning and personal growth $[8,46]$.

This assignment focuses reflecting on a critical incident and writing about it. There is neither a right nor a wrong approach to reflective practice as a pharmacy professional. You can think of it as questions to explore.

Objectives: Following completion of this assignment, you will be able to:

- Identify and explore an event you experienced that is significant to you;

- Develop a feasible action plan in response to the event.

Task: Identify a recent event or occurrence that challenged you in some way. This incident could arise from dealing with a difficult or person, making an error, or feeling discomfort with a scenario. All that matters is the event is significant to you in some way. With this event in mind, write a reflection using the prompts below as your guide.

Reflective questions to explore:

- What were your thoughts, feelings and/or reactions about the incident?

- What did you learn from this incident?

- How does your learning relate to prior thoughts, assumptions, feelings, or experiences?

- How can you apply what you learned to future situations?

Due date: <Insert date>

Submission: To be uploaded to content management system $<$ Specifics here $>$

Submission requirements: 500-word count maximum, 12-point font, double-spaced, no specific writing style required

Assessment: <indicate percentage of grade, assessment method, assessment guide>

Assignment variations: <see Table A1 below $>$

Table A1. Personal Development Reflection Assignment Options.

\begin{tabular}{|c|c|c|c|}
\hline Activity & Format & Assessment & Rationale and Resources \\
\hline $\begin{array}{l}\text { Explore feelings and emotions } \\
\text { following a critical incident }\end{array}$ & $\begin{array}{l}\text { Reflective journal entry } \\
\text { Written Essay }\end{array}$ & $\begin{array}{c}\text { Self-assessment } \\
\text { Formative with } \\
\text { instructor feedback } \\
\text { Summative with instructor } \\
\text { feedback and grade } \\
\text { assigned from rubric } \\
\text { Summative } \\
\text { (Complete/Incomplete) } \\
\text { Portfolio }\end{array}$ & $\begin{array}{l}\text { Reflection requires a significant } \\
\text { incident }[13,19,22,42]\end{array}$ \\
\hline $\begin{array}{l}\text { Apply reflections on a critical } \\
\text { incident to further learning }\end{array}$ & $\begin{array}{l}\text { Combine with a second } \\
\text { reflection following feedback } \\
\text { Develop a continuing } \\
\text { professional development plan }\end{array}$ & $\begin{array}{c}\text { Formative with } \\
\text { instructor feedback } \\
\text { Summative with instructor } \\
\text { feedback and grade } \\
\text { assigned from rubric } \\
\text { Portfolio }\end{array}$ & $\begin{array}{c}\text { Reflection improves } \\
\text { decision-making }[1,13,19,42]\end{array}$ \\
\hline Share a reflection with peers & $\begin{array}{l}\text { Blog post } \\
\text { Small group discussion } \\
\text { (asynchronous) }\end{array}$ & $\begin{array}{l}\text { Formative with peer-feedback } \\
\text { (1-2 peers, anonymous) } \\
\text { Formative with peer-feedback } \\
\text { (1-2 peers, established group) }\end{array}$ & $\begin{array}{l}\text { Sharing reflections with other } \\
\text { students improves self and } \\
\text { peer-reflective ability and } \\
\text { development }[13,19,22,42,56]\end{array}$ \\
\hline $\begin{array}{l}\text { Provide (or incorporate) peer } \\
\text { feedback techniques }\end{array}$ & $\begin{array}{l}\text { Incorporate peer assessment } \\
\text { into a selected assignment } \\
\text { (essay, blog post, portfolio, etc.) }\end{array}$ & $\begin{array}{l}\text { Formative with peer-feedback } \\
\text { (1-2 peers, anonymous) } \\
\text { Formative with peer-feedback } \\
\text { (1-2 peers, established group) }\end{array}$ & $\begin{array}{c}\text { Sharing reflections with other } \\
\text { students improves self and } \\
\text { peer-reflective ability and } \\
\text { development }[13,19,42,45,55,56]\end{array}$ \\
\hline
\end{tabular}

\section{Appendix A.2. Professional Development}

Background: Aside from learning all the material to become a professional, there is learning on how to become a professional. Professional development is a continuous and dynamic process that is utilized every time we learn or apply a new skill [47]. Continuing 
your professional learning is key as the field of pharmacy is constantly changing. In addition to this, as a professional, you are recognized as a respected individual within the community, and you need to hold yourself to high standards. Reflection itself is part of the continuing professional development process [47]. You can reflect and create a continuing professional development plan which can involve written assignments with SMART goals, planning learning activities, learning experiences, applying learning to new situations, evaluating learning, and documenting to help you further your skills.

Objectives: Following completion of this assignment, you will be able to:

- Understand the benefit of reflection for professional development;

- Identify and explore a professional skill that you plan to further develop in yourself;

- Understand the difference of reflection for professional development and a reflection on professional development.

Task: Identify an experience that challenged you to learn or develop in some way. This experience could arise from new information, a situation dealing with a difficult or emotional patient or colleague, making, or discovering an error, conflict, feeling discomfort with a situation, or any other situation. With this experience in mind, write a reflection using the prompts below as your guide.

Reflective questions to explore:

- What insights did you gain from the experience about your professional goals or skills?

- What professional skills do plan to develop?

- What professional skills do you want to practice during the experience? Why are these important to you? How will you go about this? How will you know if you are improving?

- Did the experience confirm your expectations about careers and roles in this area or were you surprised? If you were surprised, please document why?

- How does your experience impact your career path?

- How will you apply these skills?

Due Date: <To be determined by the instructor>

Submission: <To be determined by the instructor based on selected objectives>

Submission requirements: 500-word count maximum, 12-point font, double-spaced, no specific writing style required

Assessment: < indicate percentage of grade, assessment method, assessment guide > Assignment variations: <see Table A2 below >

Table A2. Personal Development Reflection Assignment Options.

\begin{tabular}{|c|c|c|c|}
\hline Activity & Format & Assessment & Rationale and Resources \\
\hline $\begin{array}{l}\text { Discuss how your notion of } \\
\text { the role of a pharmacist has } \\
\text { changed or remained the same }\end{array}$ & $\begin{array}{c}\text { Written Essay } \\
\text { Written group assignment } \\
\text { identifying a skill a } \\
\text { pharmacist needs to have }\end{array}$ & $\begin{array}{l}\text { Formative with grade } \\
\text { assigned from rubric }\end{array}$ & $\begin{array}{c}\text { Reflection aids in professional } \\
\text { development } \\
\text { Improvement of clinical } \\
\text { decision-making }[1,13,19,42]\end{array}$ \\
\hline $\begin{array}{c}\text { Discuss key skills that are } \\
\text { required for a } \\
\text { pharmacist to have }\end{array}$ & $\begin{array}{l}\text { Small group discussion } \\
\text { Continuing professional } \\
\text { development plan }\end{array}$ & Self -reflection on own time & $\begin{array}{l}\text { Sharing with other students } \\
\text { improves self and peer } \\
\text { reflective ability and } \\
\text { development }[13,19,42,55,56]\end{array}$ \\
\hline $\begin{array}{c}\text { Share a professional learning } \\
\text { plan with peers }\end{array}$ & $\begin{array}{l}\text { Blog post } \\
\text { Small group discussion } \\
\text { (asynchronous) } \\
\text { Portfolio }\end{array}$ & $\begin{array}{l}\text { Formative with peer-feedback } \\
\quad(1-2 \text { peers, anonymous) } \\
\text { Formative with peer-feedback } \\
\text { (1-2 peers, established group) }\end{array}$ & $\begin{array}{l}\text { Sharing reflections with other } \\
\text { students improves self and } \\
\text { peer-reflective ability and } \\
\text { development }[19,22,42,45,56]\end{array}$ \\
\hline
\end{tabular}

\section{Appendix A.3. Professional Identity Formation}

Background: Throughout the Doctor of Pharmacy program, the formation of a professional identity is an integral aspect of your learning. Professional identity refers to how professionals define themselves based on the work that they do. The process is both social 
and relational involving interaction between you and others. It is also an iterative process that occurs over time as you integrate the knowledge, skills, values, and behaviours of a professional. Reflective practice assists in the process of professional identity formation by linking experience with thinking, learning, and doing. Similar to reflective practice, professional identity formation starts with you (how you see your role) and extends to your interactions with others (how others see your role). In a study of pharmacy students completing early practice experiences, the process of professional identity formation involved four stages that included reflection, selection of attributes, professional socialization, and perception of the role [48].

Objectives: Following completion of this assignment, you will be able to:

- Reflect on the meaning of your role in a specific practice context;

- Identify aspects of behaviour you do or do not want to be part of your own professional identity;

- Consider how others affect your understanding or enactment of your role.

Task: Identify a recent experience in pharmacy practice where you performed some aspect of a pharmacist's role. With this experience in mind, write a reflection using the prompts below as your guide.

Reflective questions to explore:

- What was the practice experience and context? Who else did you encounter?

- How do you describe the pharmacist's role related to this experience?

- What insights did you gain from the experience about your professional role?

- What did others say about, or how did they react to, your role?

- How did other pharmacists or professionals model this role? What aspects of behaviour do you want, or not want, to be part of your own professional identity?

- Did the experience confirm your expectations about pharmacists' roles in this area or were you surprised? If surprised, please indicate the reasons why.

- Did your understanding of your role as a pharmacist change or remain the same after this experience?

- How will this experience influence how you enact this role in the future?

- Is there anything you would like to learn before you return to this role in the future?

Due date: <insert date>

Submission: <insert specifics>

Submission requirements: 500-word count maximum, 12-point font, double-spaced, no specific writing style required

Assessment: < indicate percentage of grade, assessment method, assessment guide> Assignment variations: <see Table A3 below>

Table A3. Professional Identity Formation Reflection Assignment Options.

\begin{tabular}{|c|c|c|c|}
\hline Activity & Format & Assessment & Rationale and Resources \\
\hline $\begin{array}{l}\text { Identify aspects of behaviour } \\
\text { you do or do not want to be } \\
\text { part of your own professional } \\
\text { identityConsider how others } \\
\text { affect your understanding or } \\
\text { enactment of your role }\end{array}$ & $\begin{array}{l}\text { Reflective journal entry } \\
\text { Written Essay }\end{array}$ & $\begin{array}{c}\text { Self-assessment } \\
\text { Formative with } \\
\text { instructor feedback } \\
\text { Summative with instructor } \\
\text { feedback and grade assigned } \\
\text { from rubric } \\
\text { Summative } \\
\text { (Complete/Incomplete) } \\
\text { Portfolio }\end{array}$ & $\begin{array}{c}\text { Professional identity is } \\
\text { developed though reflection } \\
\text { on experience [48] }\end{array}$ \\
\hline $\begin{array}{l}\text { Apply reflections on a critical } \\
\text { incident to further learning }\end{array}$ & $\begin{array}{l}\text { Combine with a second } \\
\text { reflection following feedback } \\
\text { Develop a continuing } \\
\text { professional } \\
\text { development plan }\end{array}$ & $\begin{array}{c}\text { Formative with instructor } \\
\text { feedback } \\
\text { Summative with instructor } \\
\text { feedback and grade assigned } \\
\text { from rubric } \\
\text { Portfolio }\end{array}$ & $\begin{array}{l}\text { Reflection improves critical } \\
\text { decision-making }[1,13,19,42]\end{array}$ \\
\hline
\end{tabular}


Table A3. Cont.

\begin{tabular}{|c|c|c|c|}
\hline Activity & Format & Assessment & Rationale and Resources \\
\hline Share a reflection with peers & $\begin{array}{c}\text { Blog post } \\
\text { Small group discussion } \\
\text { (asynchronous) }\end{array}$ & $\begin{array}{l}\text { Formative with peer-feedback } \\
\quad(1-2 \text { peers, anonymous) } \\
\text { Formative with peer-feedback } \\
\text { (1-2 peers, established group) }\end{array}$ & $\begin{array}{l}\text { Sharing reflections with other } \\
\text { students improves self and } \\
\text { peer-reflective ability and } \\
\text { development }[13,19,22,42]\end{array}$ \\
\hline $\begin{array}{l}\text { Provide (or incorporate) peer } \\
\text { feedback techniques }\end{array}$ & $\begin{array}{c}\text { Incorporate peer assessment } \\
\text { into a selected assignment } \\
\text { (essay, blog post, portfolio, } \\
\text { etc.) }\end{array}$ & $\begin{array}{l}\text { Formative with peer-feedback } \\
\quad(1-2 \text { peers, anonymous) } \\
\text { Formative with peer-feedback } \\
\text { (1-2 peers, established group) }\end{array}$ & $\begin{array}{c}\text { Sharing reflections with other } \\
\text { students improves self and } \\
\text { peer-reflective ability and } \\
\text { development } \\
{[13,19,22,42,55,56]}\end{array}$ \\
\hline $\begin{array}{l}\text { Compare experiences, } \\
\text { understanding and enactment } \\
\text { of roles in different contexts }\end{array}$ & $\begin{array}{c}\text { Small group presentations } \\
\text { Written Essay } \\
\text { Journal entry } \\
\text { Blog post } \\
\text { Presentation }\end{array}$ & $\begin{array}{c}\text { Formative with grade } \\
\text { assigned from rubric } \\
\text { Peer-feedback using a rubric } \\
\text { during discussion }\end{array}$ & $\begin{array}{c}\text { Sharing with other students } \\
\text { improves self and peer } \\
\text { reflective ability and } \\
\text { development } \\
{[13,19,22,42,55,56]} \\
\text { Reflection aids in professional } \\
\text { development and } \\
\text { improvement of clinical } \\
\text { decision-making }[13,19,22,42]\end{array}$ \\
\hline
\end{tabular}

\section{Appendix B.}

Table A4. Rubric for Assessing Reflection Assignments *

\begin{tabular}{|c|c|c|c|}
\hline Process & Non-Reflective & Reflective & Critically Reflective \\
\hline $\begin{array}{l}\text { Returning to experience: } \\
\text { Provides a clear description of } \\
\text { the experience or task }\end{array}$ & $\begin{array}{l}\text { Statement does not provide a } \\
\text { clear description of the } \\
\text { task itself }\end{array}$ & $\begin{array}{l}\text { Statement provides a } \\
\text { description of the task }\end{array}$ & $\begin{array}{l}\text { Statement provides } \\
\text { description of the task } \\
\text { chronologically and clear of } \\
\text { any judgments }\end{array}$ \\
\hline $\begin{array}{l}\text { Attending to feelings: } \\
\text { Attends to both thoughts and } \\
\text { feelings }\end{array}$ & $\begin{array}{l}\text { Statement provides little or no } \\
\text { evidence of personal } \\
\text { feelings, thoughts, } \\
\text { and reactions? }\end{array}$ & $\begin{array}{l}\text { Statement conveys some } \\
\text { personal feelings and } \\
\text { thoughts of the experience but } \\
\text { does not relate to personal } \\
\text { learning }\end{array}$ & $\begin{array}{l}\text { Statement conveys personal } \\
\text { feelings, thoughts (positive } \\
\text { and/ or negative) of the } \\
\text { experience and relates to } \\
\text { future personal learning }\end{array}$ \\
\hline $\begin{array}{l}\text { Associating: } \\
\text { Relates new knowledge with } \\
\text { previous knowledge }\end{array}$ & $\begin{array}{l}\text { Statement does not provide } \\
\text { any relationship between new } \\
\text { knowledge with previous } \\
\text { knowledge }\end{array}$ & $\begin{array}{l}\text { Statement provides evidence } \\
\text { that perhaps prior knowledge } \\
\text { may be consistent with new } \\
\text { knowledge gained through } \\
\text { this task }\end{array}$ & $\begin{array}{l}\text { Statement clearly relates new } \\
\text { knowledge learned with } \\
\text { previous knowledge and sees } \\
\text { that accommodating new } \\
\text { knowledge will assist with } \\
\text { future practice }\end{array}$ \\
\hline $\begin{array}{l}\text { Integrating: } \\
\text { Integrates prior knowledge, } \\
\text { feelings, or attitudes with new } \\
\text { knowledge }\end{array}$ & $\begin{array}{l}\text { Statement shows no evidence } \\
\text { of integration of prior } \\
\text { knowledge, feelings, or } \\
\text { attitudes with new } \\
\text { knowledge, feelings, or } \\
\text { attitudes, thus not arriving at } \\
\text { new perspectives }\end{array}$ & $\begin{array}{l}\text { Statement provides some } \\
\text { evidence of integration prior } \\
\text { knowledge, feelings or } \\
\text { attitudes with new } \\
\text { knowledge, feelings or } \\
\text { attitudes and arriving at a } \\
\text { new perspective }\end{array}$ & $\begin{array}{l}\text { Statement clearly provides } \\
\text { evidence of integration of } \\
\text { prior knowledge, feelings or } \\
\text { attitudes with new } \\
\text { knowledge, feelings or } \\
\text { attitudes, thus arriving at new } \\
\text { perspectives }\end{array}$ \\
\hline $\begin{array}{l}\text { Assessing: } \\
\text { Self-assesses prior beliefs, } \\
\text { approaches, assumptions in } \\
\text { relation to experience }\end{array}$ & $\begin{array}{l}\text { Statement shows no evidence } \\
\text { of self-reflection and } \\
\text { self-assessing of previously } \\
\text { held beliefs, assumptions, } \\
\text { approaches and does not } \\
\text { relate it to previous experience }\end{array}$ & $\begin{array}{l}\text { Statement demonstrates } \\
\text { self-reflection, self-assessment } \\
\text { of previously held beliefs, } \\
\text { assumptions, approaches, and } \\
\text { occasionally relates it to } \\
\text { previous experience and } \\
\text { previous knowledge }\end{array}$ & $\begin{array}{l}\text { Statements clearly conveys } \\
\text { self-reflection and } \\
\text { self-assessment of previously } \\
\text { held beliefs, assumptions, } \\
\text { approaches, consistently } \\
\text { relating it to previous } \\
\text { experience and previous } \\
\text { knowledge }\end{array}$ \\
\hline
\end{tabular}


Table A4. Cont.

\begin{tabular}{lll}
\hline \multicolumn{1}{c}{ Process } & \multicolumn{1}{c}{ Non-Reflective } & \multicolumn{1}{c}{ Reflective } \\
\hline $\begin{array}{l}\text { Internalizing: } \\
\text { Adapts the information in a }\end{array}$ & Statement does not indicate & $\begin{array}{l}\text { Statement shows owning of } \\
\text { knowledge and makes } \\
\text { way that is personally }\end{array}$ \\
$\begin{array}{l}\text { meaningful; applies new } \\
\text { knowledge as own }\end{array}$ & owning of knowledge & $\begin{array}{l}\text { knowledge and prior } \\
\text { experience }\end{array}$
\end{tabular}

Statement clearly shows evidence that inferences have been made using their own prior knowledge and previous experience throughout the task

Statement clearly shows evidence of reflection and:

\section{Changing:}

Describes how reflection led to change or supports future change; applies outcome of reflection to create new practices
Statement shows little or no reflection on own work, does not show how to improve knowledge or behaviour and does not provide any examples for future improvement
Statement shows some evidence of reflecting on own work, shows evidence to apply new knowledge with relevance to future practice for improvement of future pharmacy practice. Provides examples of possible new actions that can be implemented most of the time.
1. States a change in behaviour or development of new perspective as a result of the experience or task

2. Shows ability to reflect on own task, apply new knowledge feelings, thoughts, opinions, to enhance new or future experiences

3. Provides specific examples

${ }^{*}$ Modified version of the Reflective Rubric to Assess Reflective Writing in Pharmacy Education [44,45].

\section{Appendix C. Implementation of Reflection Assignment Template}

Introduction

Reflection can be defined as "the process of engaging the self in attentive, critical, exploratory and iterative interactions with one's thoughts and actions, and their underlying conceptual frame, with a view to changing them and with a view on the change itself" [2] (p. 1182).

The process of reflection starts with you. This means that reflecting, and developing your own reflective approach, is important before you can begin to assess the words, ideas, and perspectives of others. Applying a reflective process enables you to identify and examine your own thoughts, feelings, and reactions. Reflective practice involves:

- Revisiting your prior experience and knowledge of the topic you are exploring;

- Considering how and why you think the way you do;

- Examining your beliefs, values, attitudes, and assumptions that form the foundation of your understanding;

- Recognizing that you bring valuable knowledge to every experience;

- Clarifying important connections between what you already know and what you are learning;

- Becoming an active, aware, and critical thinker and learner;

- Identifying how reflection leads to change, supports future change, or new practices, approaches and/or strategies.

When you write your reflections, you are:

- Documenting your response to experiences, opinions, events, or new information;

- Communicating your response by evaluating your own thoughts, feelings, and reactions;

- Seizing an opportunity to "start with you" or gain self-knowledge;

- Applying a way that professions learn;

- Achieving clarity and better understanding of what you are learning;

- Developing and reinforcing writing skills;

- Making meaning out of what you study as a professional.

Reflection Assignment: Personal Development (Critical Incident) 
Background: A critical incident is a learning situation which learners have experienced as effective, exceptional, or personally meaningful which may lead to educationally significant learning and personal growth $[8,46]$.

This assignment focuses on reflecting on a critical incident and writing about it. There is neither a right nor a wrong approach to reflective practice as a pharmacy professional. You can think of it as questions to explore.

Objectives: Following completion of this assignment, you will be able to:

- Explore an event you experienced in lab that is significant to you

- Develop a feasible action plan in response to the event

- Deal with conflicting emotions from other healthcare professionals

Task: After taking the time to interview your patient, conduct a care plan, prepare documentation, and share your findings with the physician, including your intervention/recommendation of starting perindopril/indapamide, the physician sends back a faxed letter informing you that he does not agree with your proposed plan. Describe the situation. How would you respond to the physician? Is there only one way to address the patient's health needs? Is the experience of the physician important in this situation? Did this scenario make you feel discomfort? With this event in mind, write a reflection using the prompts below as your guide.

Reflective questions to explore:

- What were your thoughts, feelings and/or reactions about the incident?

- What did you learn from this incident?

- How does your learning relate to prior thoughts, assumptions, feelings, or experiences?

- How can you apply what you learned to future situations?

- How did this guided group reflection help you in writing an informed response to the physician? (Added for the Group Reflection)

Due date: Friday, October 23 at noon

Submission: eClass

Submission requirements: Maximum 500-word count, minimum 11-point font, doublespaced, no specific writing style required. 4 paragraphs recommended.

Assessment: Formative feedback using rubric provided [Appendix B].

\section{References}

1. Tsingos-Lucas, C.; Bosnic-Anticevich, S.; Schneider, C.R.; Smith, L. The effect of reflective activities on reflective thinking ability in an undergraduate pharmacy curriculum. Am. J. Pharm. Educ. 2016, 80, 65. [CrossRef]

2. Nguyen, Q.D.; Fernandez, N.; Karsenti, T.; Charlin, B. What is reflection? A conceptual analysis of major definitions and a proposal of a five-component model. Med. Educ. 2014, 48, 1176-1189. [CrossRef]

3. Ryan, M.; Ryan, M. Theorising a model for teaching and assessing reflective learning in higher education. High. Educ. Res. Dev. 2013, 32, 244-257. [CrossRef]

4. Dewey, J. How We Think: A Restatement of the Relation of Reflective Thinking to the Educative Process; D. C Health: Boston, MA, USA, 1933.

5. Boud, D.; Keogh, R.; Walker, D. Reflection: Turning Experience into Learning; Kogan Page: London, UK, 1985.

6. Mezirow, J. Fostering Critical Reflection in Adulthood; Jossey-Bass: San Francisco, CA, USA, 1990.

7. Kolb, D.A. Experiential Learning: Experience as the Source of Learning and Development; Prentice-Hall: Englewood Cliffs, NJ, USA, 1984.

8. Brookfield, S. Developing Critical Thinkers: Challenging Adults to Explore Alternative Ways of Thinking and Acting, 1st ed.; Jossey-Bass: San Francisco, CA, USA, 1987.

9. Schön, D.A. The Reflective Practitioner: How Professionals Think in Action; Basic Books: New York, NY, USA, 1983.

10. Chan, C.K.Y.; Lee, K.K.W. Reflection literacy: A multilevel perspective on the challenges of using reflections in higher education through a comprehensive literature review. Educ. Res. Rev. 2021, 32, 100376. [CrossRef]

11. Fullana, J.; Pallisera, M.; Colomer, J.; Fernández Peña, R.; Pérez-Burriel, M. Reflective learning in higher education: A qualitative study on students' perceptions. Stud. High. Educ. 2016, 41, 1008-1022. [CrossRef]

12. Tan, S.Y. Reflective learning? Understanding the student perspective in higher education. Educ. Res. 2021, 63, 229-243. [CrossRef]

13. O'Reilly, S.L.; Milner, J. Transitions in reflective practice: Exploring student development and preferred methods of engagement. Nutr. Diet. 2015, 72, 150-155. [CrossRef]

14. McCarthy, B.; Bessell, N.; Murphy, S.; Hartigan, I. Nursing and speech and language students' perspectives of reflection as a clinical learning strategy in undergraduate healthcare education: A qualitative study. Nurse Educ. Pract. 2021, 57, 103251. [CrossRef] [PubMed] 
15. Mann, K.; Gordon, J.; MacLeod, A. Reflection and reflective practice in health professions education: A systematic review. Adv. Health Sci. Educ. Theory Pract. 2009, 14, 595-621. [CrossRef]

16. Er, H.M.; Ming, M.K.J.; Keng, P.S.; Nadarajah, V.D. Pharmacy students' perceptions of reflective portfolios and their effect on students' deep information-processing skills. Am. J. Pharm. Educ. 2019, 83, 1343-1353. [CrossRef]

17. Tsingos-Lucas, C.; Bosnic-Anticevich, S.; Schneider, C.R.; Smith, L. Using reflective writing as a predictor of academic success in different assessment formats. Am. J. Pharm. Educ. 2017, 81, 8. [CrossRef]

18. King, A.E.; Joseph, A.S.; Umland, E.M. Student perceptions of the impact and value of incorporation of reflective writing across a pharmacy curriculum. Curr. Pharm. Teach. Learn. 2017, 9, 770-778. [CrossRef]

19. Tsingos, C.; Bosnic-Anticevich, S.; Smith, L. Reflective practice and its implications for pharmacy education. Am. J. Pharm. Educ. 2014, 78, 18. [CrossRef]

20. Deslandes, R.; Lucas, C.; Hughes, M.L.; Mantzourani, E. Development of a template to facilitate reflection among student pharmacists. Res. Soc. Adm. Pharm. 2018, 14, 1058-1063. [CrossRef]

21. Guo, L. How should reflection be supported in higher education?-A meta-analysis of reflection interventions. Reflective Pract. 2021, 23, 118-146. [CrossRef]

22. Sandars, J. The use of reflection in medical education: AMEE Guide No. 44. Med. Teach. 2009, 31, 685-695. [CrossRef]

23. Tsingos, C.; Bosnic-Anticevich, S.; Smith, L. Does a learning style preference for processing information through reflection impact on the academic performance of a cohort of undergraduate pharmacy students? Pharm. Educ. 2015, 15, $233-240$.

24. Fernández-Peña, R.; Fuentes-Pumarola, C.; Malagón-Aguilera, M.C.; Bonmatí-Tomàs, A.; Bosch-Farré, C.; Ballester-Ferrando, D. The evaluation of reflective learning from the nursing student's point of view: A mixed method approach. Nurse Educ. Today 2016, 44, 59-65. [CrossRef]

25. Vivekananda-Schmidt, P.; Marshall, M.; Stark, P.; McKendree, J.; Sandars, J.; Smithson, S. Lessons from medical students' perceptions of learning reflective skills: A multi-institutional study. Med. Teach. 2011, 33, 846-850. [CrossRef]

26. Song, P.; Stewart, R. Reflective writing in medical education. Med. Teach. 2012, 34, 955-956. [CrossRef]

27. Bovill, C.; Cook-Sather, A.; Felten, P.; Millard, L.; Moore-Cherry, N. Addressing potential challenges in co-creating learning and teaching: Overcoming resistance, navigating institutional norms and ensuring inclusivity in student-staff partnerships. High. Educ. 2016, 71, 195-208. [CrossRef]

28. University of Alberta. Doctor of Pharmacy (PharmD). Available online: https://calendar.ualberta.ca/preview_program.php? catoid=34\&poid=38931\&hl=\%22pharmacy\%22\&returnto=search (accessed on 14 December 2021).

29. University of Alberta. Faculty of Pharmacy and Pharmaceutical Sciences Admission Requirements. Available online: https: / / calendar.ualberta.ca / content.php?catoid=34\&navoid=10234 (accessed on 14 December 2021).

30. Association of Faculties of Pharmacy of Canada. AFPC Educational Outcomes for First Professional Degree Programs in Pharmacy in Canada 2017; Association of Faculties of Pharmacy of Canada: Toronto, ON, Canada, 2017.

31. Schindel, T.J.; Hughes, C.A.; Sadowski, C.A. Blended learning: Reflections on Teaching experiences across the pharmacy education continuum. Pharmacy 2013, 1, 137. [CrossRef]

32. Nagy, D.K.; Hall, J.J.; Charrois, T.L. The impact of the COVID-19 pandemic on pharmacy students' personal and professional learning. Curr. Pharm. Teach. Learn. 2021, 13, 1312-1318. [CrossRef]

33. Lubicz-Nawrocka, T.; Bovill, C. Do students experience transformation through co-creating curriculum in higher education? Teach. High. Educ. 2021. [CrossRef]

34. Bovill, C. Co-creation in learning and teaching: The case for a whole-class approach in higher education. High. Educ. 2020, 79, 1023-1037. [CrossRef]

35. Könings, K.D.; Mordang, S.; Smeenk, F.; Stassen, L.; Ramani, S. Learner involvement in the co-creation of teaching and learning: AMEE Guide No. 138. Med. Teach. 2021, 43, 924-936. [CrossRef]

36. Bovill, C.; Cook-Sather, A.; Felten, P. Students as co-creators of teaching approaches, course design, and curricula: Implications for academic developers. Int. J. Acad. Dev. 2011, 16, 133-145. [CrossRef]

37. Branch, R.M. Instructional Design: The ADDIE Approach; Springer: New York, NY, USA, 2008.

38. Peterson, C. Bringing ADDIE to life: Instructional design at its best. J. Educ. Multimed Hypermedia 2003, 12, $227-241$.

39. Brown, A.; Jauregui, J.; Ilgen, J.S.; Riddell, J.; Schaad, D.; Strote, J.; Shandro, J. Does the medium matter? Evaluating the depth of reflective writing by medical students on social media compared to the traditional private essay using the REFLECT rubric. West. J. Emerg. Med. 2019, 21, 18-25. [CrossRef] [PubMed]

40. Hughes, J.A.; Cleven, A.J.; Ross, J.; Fuentes, D.G.; Elbarbry, F.; Suzuki, M.; Paolera, M.D.; Carter, N.S.; Stamper, B.; Low, P.; et al. A comprehensive reflective journal-writing framework for pharmacy students to increase self-awareness and develop actionable goals. Am. J. Pharm. Educ. 2019, 83, 312-322. [CrossRef]

41. Lack, L.; Yielder, J.; Goodyear-Smith, F. Evaluation of a compulsory reflective group for medical students. J. Prim. Health Care 2019, 11, 227-234. [CrossRef]

42. Tsingos, C.; Bosnic-Anticevich, S.; Lonie, J.M.; Smith, L. A model for assessing reflective practices in pharmacy education Am. J. Pharm. Educ. 2015, 79, 124. [CrossRef]

43. Ash, S.L.; Clayton, P.H. Generating, deepening, and documenting learning: The power of critical reflection in applied learning. JALHE 2009, 1, 25-48. 
44. Lucas, C.; Bosnic-Anticevich, S.; Schneider, C.R.; Bartimote-Aufflick, K.; McEntee, M.; Smith, L. Inter-rater reliability of a reflective rubric to assess pharmacy students' reflective thinking. Curr. Pharm. Teach. Learn. 2017, 9, 989-995. [CrossRef]

45. Lucas, C.; Smith, L.; Lonie, J.M.; Hough, M.; Rogers, K.; Mantzourani, E. Can a reflective rubric be applied consistently with raters globally? A study across three countries. Curr. Pharm. Teach. Learn. 2019, 11, 987-994. [CrossRef]

46. Soini, H. Critical Learning Incidents. In Encyclopedia of the Sciences of Learning; Seel, N.M., Ed.; Springer: Boston, MA, USA, 2012; pp. 846-848.

47. Rouse, M.J.; Trewet, C.B.; Janke, K.K. Advancing learning to advance pharmacy practice. J. Am. Pharm. Assoc. 2018, 58, 151-155. [CrossRef]

48. Quinn, G.; Lucas, B.; Silcock, J. Professional identity formation in pharmacy students during an early preregistrationtTraining placement. Am. J. Pharm. Educ. 2020, 84, ajpe7804. [CrossRef]

49. Knafl, K. Cognitive Interview. In The SAGE Encyclopedia of Qualitative Research Methods; Given, L.M., Ed.; SAGE Publications, Inc.: Thousand Oaks, CA, USA, 2008; Volume 1, pp. 90-91.

50. Palys, T. Purposive Sampling. In The SAGE Encyclopedia of Qualitative Research Methods; Given, L.M., Ed.; SAGE Publications, Inc.: Thousand Oaks, CA, USA, 2008; Volume 1, p. 698.

51. Gilliam, E.H.; Brunner, J.M.; Bolan, J.; Lee, S.; Nuffer, W.; Franson, K.L.; Thompson, M.E. Cultivating a culture of reflection among pharmacy students through storytelling. Am. J. Pharm. Educ. 2020, 84, 7633. [CrossRef]

52. Medina, M.S.; Plaza, C.M.; Stowe, C.D.; Robinson, E.T.; DeLander, G.; Beck, D.E.; Melchert, R.B.; Supernaw, R.B.; Roche, V.F.; Gleason, B.L.; et al. Center for the Advancement of Pharmacy Education 2013 Educational Outcomes. Am. J. Pharm. Educ. 2013, 77, 162. [CrossRef]

53. Breault, R.R.; Schindel, T.J.; Hughes, C.A. Pharmacist care planning services: What matters most. Can. Pharm. J. 2021, 154, 149-152. [CrossRef]

54. Lucas, C.; Gibson, A.; Shum, S.B. Pharmacy students' utilization of an online tool for immediate formative feedback on reflective writing tasks. Am. J. Pharm. Educ. 2019, 83, 1260-1267. [CrossRef]

55. Lucas, C. Accessorizing the Science Foundation with Internal Mirrors: A Novel Open Source Tool to Enhance Reflective Practice Pulses 2018. Available online: https:/ / cptlpulses.com/2018/08/28/lucas-reflectivepractice/ (accessed on 6 January 2022).

56. Mishra, S.D.; Rebitch, C.B.; Choi, I. Exploring student perceptions and attitude towards various aspects of peer feedback in a pharmacotherapy course. Curr. Pharm. Teach. Learn. 2020, 12, 701-708. [CrossRef]

57. Dollinger, M.; Lodge, J.; Coates, H. Co-creation in higher education: Towards a conceptual model. J. Mark. High. Educ. 2018, 28, 210-231. [CrossRef]

58. Milles, L.S.; Hitzblech, T.; Drees, S.; Wurl, W.; Arends, P.; Peters, H. Student engagement in medical education: A mixed-method study on medical students as module co-directors in curriculum development. Med. Teach. 2019, 41, 1143-1150. [CrossRef]

59. Harding, G.; Taylor, K. Why pharmacists are needed to help shape students' professional identity. Pharm. J. 2006, $277,766$.

60. Janke, K.K.; Wilby, K.J.; Zavod, R. Academic writing as a journey through "chutes and ladders": How well are you managing your emotions? Curr. Pharm. Teach. Learn. 2020, 12, 103-111. [CrossRef] 